\title{
DIETRICHA BONHOEFFERA \\ KRYTYKA TEOLOGII LIBERALNEJ
}

\author{
Helena Anna Jędrzejczak \\ Uniwersytet Warszawski
}

\section{/// Wstęp}

Eberhard Bethge, przyjaciel i wychowanek Dietricha Bonhoeffera, zapisał na początku lat 30., że „teolog nawrócił się na chrześcijanina”.

Przedstawiciele Deutsche Christen, dominującej, a później praktycznie jedynej siły w Ewangelickim Kościele Niemiec (Evangelisches Kirche Deutschland), zarzucali Bonhoefferowi: kryptokatolicyzm, monastycyzm, niepotrzebne oraz niewłaściwe manifestowanie religijności. O prowadzonym przezeń seminarium kaznodziejskim Kościoła Wyznającego w Finkenwalde (dziś Szczecin-Zdroje) krążyły opowieści o iście monastycznym sposobie życia grupy marzycieli, fanatyków i heretyków (por. Bethge 2003: 51-59).

Te dwa cytaty właściwie mogłyby służyć za streszczenie niniejszego artykułu - pokazują bowiem efekt procesów intelektualnych i zmagań Bonhoeffera ze współczesną mu ewangelicką teologią niemiecką (w tym: przedstawicielami akademickiej teologii liberalnej), a po części także ich przyczyny. Ewangelicka teologia liberalna pierwszej połowy XX wieku nie jest obiektem powszechnego zainteresowania, a Bonhoefferowska z nia polemika jest pod wieloma względami wyjątkowa. Tę wyjątkowość myśli, postawy i wynikających z nich działań chcę pokazać w poniższym tekście.

W jego pierwszej części przedstawię filozoficzne i historyczne źródła teologii liberalnej i omówię jej główne założenia oraz konsekwencje, które z teologii liberalnej miały wynikać dla dalszego uprawiania teologii ewangelickiej w ogóle. Pozwoli to na nakreślenie kontekstu, w jakim Bonhoeffer pracował i tworzył, a także na postawienie tezy związanej ze szczególną odwaga, jakiej ta twórczość i działalność duszpasterska wymagały. 
W części drugiej pokażę, w jaki sposób Bonhoeffer polemizował z opisanymi wcześniej tezami i praktyką części przedstawicieli szerszego nurtu, jakim była niemiecka ewangelicka teologia liberalna. Polemika ta miała charakter zarówno teoretyczny (w postaci tekstów i wystapień publicznych), jak i praktyczny (w postaci podjętych decyzji wpływających na jego życie i skutkujących wyrokiem śmierci). Dlatego też artykuł zawiera nieuniknione w moim odczuciu wątki biograficzne - bez odwołania się do podjętych działań i towarzyszących im konsekwencji idee Bonhoeffera pozostałyby jedynie pustymi słowami. Był on bowiem jednym z tych teologów, którzy w największym bodaj stopniu wypełnili koncepcję nakreśloną przez Lutra: „Prawdziwym teologiem zostaje się nie przez filozofowanie i spekulacje, lecz przez życie, pośród pokus i walk, w których trzeba wytrwać” (cyt. za Kopiec 2008: 5). Czasy, w których Bonhoefferowi przyszło żyć, i sposób, w jaki rozumiał swe chrześcijaństwo, sprawiły, że praktycznie całe jego życie wymagało wytrwania w walce. Niepozbawionej rzecz jasna filozoficznego namysłu nad kondycją człowieka i chrześcijanina, ale wymagającej gotowości do złożenia ofiary z samego siebie.

\section{/// Źródła teologii liberalnej}

By zrozumieć fenomen teologii liberalnej (a także jej krytyki dokonanej przez Bonhoeffera), konieczne jest osadzenie jej w szerszym kontekście, budowanym przez teologię niemiecką (a raczej niemieckojęzyczna). Dla jej scharakteryzowania kluczowe są trzy elementy: gruntowna, naukowa analiza Pisma Świętego, nastawienie na twórczą i nauczycielską rolę teologa oraz silny związek teologii z władzą i doktryną polityczną, tworzącymi specyficzne kulturowo-polityczne zjawisko „niemieckości”, niezależnej od formy politycznej, jaką Niemcy aktualnie przybierały ${ }^{1}$, choć oczywiście zależnej od władzy.

Tomasz Węcławski we wstępie do zbioru Praeceptores. Teologia $i$ teologowie jezyka niemieckiego tak tę ostatnią charakteryzuje:

\footnotetext{
${ }^{1}$ Oczywiście niemieckość także jest kształtowana przez kwestie religijne; w przypadku Niemiec ten czynnik jest szczególnie istotny dla budowania tożsamości kulturowej i politycznej. Więcej pisze o tym zjawisku Heinz Schilling w książce Konfesjonalizacja. Kościót i państwo w Europie doby prz̨ednowoczesnej i szereg autorów esejów zebranych przez Huberta Orłowskiego w tomie Sonderweg. Spory o ,niemiecka droge odrębna”. Pozwoliłam sobie na pewne uproszczenie, sprowadzając „niemieckość” do wpływu polityki, kultury i kwestii narodowych na tworzenie się teologii. Oczywiście niemożliwym jest wyabstrahowanie niemieckiej teologii z niemieckiej kultury; w tym przypadku chcę jednak zwrócić szczególną uwagę na jeden z kierunków tej interakcji.
} 
Teologia tworzona przez autorów niemieckojęzycznych [...] wykazuje przez stulecia pewne charakterystyczne cechy, które pozwalają traktować ja przy całym zróżnicowaniu epok, metod i stylów jako jedno zjawisko kulturowe [...]. [W teologii niemieckiej] mamy do czynienia z połączeniem dwu istotnych cech „praeceptorskich”: rzeczywistej, gruntownej i systematycznej wiedzy i pewnej skłonności do pouczania z wysokości katedry - zwłaszcza akademickiej (2005, 2007: 7-8).

Nierozerwalny związek władzy religijnej z niemiecką władzą świecką datuje się od podziału niemieckich księstw i krajów związkowych na katolickie i protestanckie, poprzez dekret Fryderyka Wilhelma III (1811) i Unię Staropruską (1817), które czyniły duchownych ewangelickich urzędnikami państwowymi, po podporządkowanie niemieckich Kościołów nazistowskiej władzy po 1933 roku. Jego uzasadnieniem ma być interpretacja Pawłowego Listu do Rzymian, bodaj najczęściej interpretowanego fragmentu Pisma Świętego, a konkretnie pierwszych siedmiu wersów jego 13. rozdziału, nakazujących posłuszeństwo chrześcijan wobec władz politycznych. Dobrym chrześcijaninem miał być więc ten, kto był dobrym obywatelem.

Ponieważ wszelkie decyzje i nauka w kwestiach politycznych miały być domeną władz państwowych, wiara i religia siła rzeczy stawały się kwestiami o charakterze wyłącznie prywatnym, osobistym i niezwiązanym z działalnością publiczną; o ile dobry chrześcijanin powinien być zaangażowany w pracę na rzecz państwa, działalność społeczną i pracę zawodową (wypełniając w ten sposób nakazy Drugiego Listu św. Pawła do Tesaloniczan), o tyle wiara miała pozostawać kwestią prywatną, nie eksponowaną w przestrzeni publicznej.

$\mathrm{Na}$ takim gruncie, zwłaszcza w dobie akademickiego neopozytywizmu, powstanie myśli teologicznej stanowiącej w gruncie rzeczy nie nauczanie, ale historyczne analizy i intelektualne przygody interpretacyjne, było tylko kwestią czasu. Czasu, który nadszedł w drugiej połowie XIX stulecia i trwał blisko sto lat. Charakterystyczne było dla niego prowadzenie historyczno-krytycznych badań biblijnych źródeł wiary i częściowe zerwanie sztywnego związku z tradycyjnymi dogmatami chrześcijaństwa. Jednym z głównych nurtów badań teologii liberalnej stały się próby historycznego odtworzenia życia Chrystusa, a nie - jak w przypadku większości innych nurtów teologii - Jego nauczania i prób odnoszenia tegoż do życia współczesnego człowieka, tak by to życie stało się Jego naśladowaniem. Co ważne, program teologii liberalnej miał nie tyle stanowić dostosowanie 
teologii do standardów uprawiania nauki opartej na poznaniu (co jest niemożliwe), ile dać odpowiedź na ówczesne problemy, w tym zwłaszcza tzw. protestantyzm kulturowy.

Protestantyzm kulturowy można rozumieć dwojako. Albo jako sprowadzenie protestantyzmu (któregoś z wyznań ewangelickich) jedynie do tradycji i kultury (bez uwzględniania treści religijnych, Objawienia etc.), albo tak, jak ujął to ewangelicki teolog, uczeń Hegla i profesor uniwersytetu w Heidelbergu - Richard Rothe ${ }^{2}$. W jego myśli teologia kultury łączy się z tradycją idealizmu niemieckiego, co prowadzić ma do „zlania się” państwa i Kościoła w jedno. Rothe uważa, że państwo potrzebuje wsparcia instytucji Kościoła, ponieważ to ona wyznacza właściwy kierunek w codziennych wyborach moralnych. Twierdzi też, że kiedy państwo dojdzie do doskonałości etycznej, kiedy się w pełni schrystianizuje, będzie mogło wraz z Kościołem stanowić jedność. W koncepcji Richarda Rothego stanem docelowym będzie sytuacja, w której społeczeństwo dojdzie do perfekcji duchowej, dzięki czemu państwo i Kościół staną się tożsame, co doprowadzi do obumarcia i rozpłynięcia się Kościoła we w pełni chrześcijańskim państwie. Społeczeństwo takiego państwa miałoby być jednocześnie moralne i religijne, ponieważ pojęcia te byłyby tożsame.

Oznacza to, że nawet na drodze do idealnego państwa schrystianizowanego i tożsamego z Kościołem religijność miałaby się manifestować w moralności zgodnej z przepisami państwowymi, które swoja treścią miałyby motywować do doskonalenia moralnego. Rothe pragnie wyłączenia dziedziny etyki i moralności z Kościoła, a jednocześnie, by stały się raczej elementem pracy państwa. W tej koncepcji, wprost wypływającej z nauki Schleiermachera, chrześcijanin jest powołany przede wszystkim do pracy kulturalnej - w ten sposób buduje Królestwo Boże. Opiera się ona na założeniu, że „spotkanie człowieka i religii, państwa i Kościoła jest możliwe w obszarze wartości etycznych i obyczajowych" (Hintz 2003: 274). Kwestia posłuszeństwa wobec władz politycznych nie jest przedmiotem namysłu, rozważań teologicznych czy nauki udzielanej w ramach pracy duszpasterskiej. Jest oczywistością, ponieważ państwo (w założeniu) służy dążeniu do Królestwa Bożego, co sprawia, że Kościół może mu w pełni podlegać, mając jednocześnie poczucie, że jest wspierany w swej pracy i w dziele.

Teologia Richarda Rothego ma charakter spekulatywny, a nie praktyczny lub historyczny. Jego rozważania, prowadzące do w pełni teokratycznej koncepcji państwa, nie sa programem reformy państwa i Kościoła, ale abstrakcyjnym rozważaniem teologa akademickiego. Jednakże w Niem-

\footnotetext{
${ }^{2}$ Więcej: http://www.britannica.com/biography/Richard-Rothe; dostęp: 23.07.2015.
}

\section{/ $144 \quad$ STANRZECZY 2[9]/2015}


czech, na uniwersytetach wypełnionych duchem heglowskiego idealizmu, spekulatywna teologia protestantyzmu kulturowego stała się podstawą dla kolejnych, jeszcze dalej idących koncepcji zlania się państwa z Kościołem, które wcielono w życie w latach 30. XX wieku i które odnajdujemy w Ordnungstheologie i u niektórych przedstawicieli teologii liberalnej.

\section{/// Teologia liberalna - koncepcje}

Niemiecka ewangelicka teologia liberalna w założeniu była programem obrony wiary i nauki Chrystusa przed akademickim neopozytywizmem dyskredytującym teologię jako taka, wyrzucającym ja poza nawias uniwersytetów przesiąkniętych duchem heglowskiego idealizmu. Miała służyć wsparciu teologii za pomocą narzędzi właściwych ówczesnej nauce, pokazywać, że przekonania religijne, nauczanie Kościołów i naśladowanie Chrystusa nie stoją w sprzeczności z zasadami rozumu i metodami poznania naukowego.

Teologia liberalna, której głównymi przedstawicielami byli David Friedrich Strauss, Friedrich Daniel Ernst Schleiermacher i Rudolf Bultmann, była silnie zakorzeniona w niemieckiej tradycji konfesyjnej, z jednej strony nierozerwalnie wiążącej władzę religijna z władzą świecką, a z drugiej czyniącej z religii kwestię prywatna, odrębna od problemów społecznych i politycznych. Po pierwsze, miała odpowiadać na koncepcje protestantyzmu kulturowego (całkowicie oddającego pole etyki i moralności pod jurysdykcję państwa), po drugie, na próby uznania całej religii i teologii za bezwartościowe, bo niemożliwe do potwierdzenia. Warunkiem wpisania się teologii liberalnej w akademicką debatę (co czyniło ją również ,godną zaufania" dla elit intelektualnych) było prowadzenie historyczno-krytycznych badań nad Pismem Świętym tak, by móc wykazywać jego brak sprzeczności z poznaniem rozumowym i brak opozycji między rozumem a wiara. Podsumowując, teologia liberalna jest teologia apologetyczną, wykorzystującą metody typowe dla nauki w celu wzięcia w obronę wiary.

Za preludium do powstania teologii liberalnej można uznać pisma myślicieli XVIII-wiecznych: Hermana S. Reimarusa, który za podstawę prawdziwości Pisma uznaje ludzki rozum (Apologia albo Pismo w obronie rozumnych çcicieli Boga) czy Gottholda E. Lessinga, podającego w wątpliwość historyczną wiarygodność chrześcijańskiego Objawienia, a także wywodzącego z luteranizmu przyzwolenie na dowolne właściwie poszukiwania prawdy i drogi do zbawienia (Pisma teologiczno-krytyczne i filozoficzne). Nie bez znaczenia pozostaje oczywiście także Kantowska Religia w obrebie samego rozumu. 
Jednak podstawowym czy może raczej sztandarowym dla teologii liberalnej tekstem jest dzieło Davida Friedricha Straussa z 1835 roku Das Leben Jesu kritisch bearbeitet (Życie Jezusa krytycznie opracowane). Strauss podejmuje w nim radykalna polemikę zarówno z heglowską koncepcja syntezy dziejów, jak i z dotychczasowym sposobem uprawiania teologii, a więc przyjęciem prawd objawionych w Piśmie Świętym jako pewnej całości, uznaniem historyczności Biblii za komplementarną wobec wiary w zmartwychwstanie Chrystusa. We Wsteptie do tegoż dzieła pisze:

Najbardziej uczonym i przenikliwym teologom naszej epoki brak jest na ogół owej zasadniczej przesłanki koniecznej w tego typu pracy, bez której na obszarze krytyki przy całej uczoności nic zdziałać się nie da, czyli wewnętrznego uwolnienia umysłu i myślenia od pewnych religijnych i dogmatycznych założeń [...]. Nawet jeśli teolodzy uznają taki brak założeń jego [Autora] dzieła za niechrześcijański, to Autor uznaje religijne założenia ich dzieł za nienaukowe (1835: 686, 2005, 2007: 305).

Zwłaszcza ostatnie przytoczone zdanie jest symptomatyczne dla teologii liberalnej. O ile inne szkoły czy nurty teologiczne zakładały współistnienie, o tyle w ujęciu Straussa nic, co nie spełnia zasad „naukowości” ustanowionych przez teologię liberalna, nie jest nauką i eo ipso nie stanowi argumentu w polemice z jej ustaleniami i założeniami. A co nie jest nauka - nie ma racji bytu.

Szczególnie interesująca jest polemika Straussa z Heglem. Dla ujawniania się Ducha dziejów (por. Hegel 1958) w postaci syntezy tego, co ludzkie, i tego, co boskie, historyczna osoba Jezusa Chrystusa, Jego życie, śmierć i zmartwychwstanie są momentami koniecznymi. Strauss nie odrzuca koncepcji heglowskiej filozofii dziejów w całości. Uznaje jednak, że do opisanej syntezy prowadzi długi proces „prób” i że ma ona charakter możliwości niezależnej od objawienia historycznego.

Historyczno-krytyczne badanie Pisma Świętego opierało się przede wszystkim na jego analizie pod względem prawdziwości, rozumianej jako neopozytywistyczna naukowość - możliwość potwierdzenia zawartych w nim treści innymi źródłami, uznanymi wcześniej za wiarygodne - historyczność i logiczna spójność. Tak rozumiane badania teologii liberalnej miały szczególny wydźwięk w zderzeniu z ewangelicką zasadą Sola Scriptura, stawiająca Słowo Boże w Piśmie Świętym Starego i Nowego Testamentu za jedyne autorytatywne źródło wiary i nauki chrześcijańskiej. To, co stano-

\section{/ $146 \quad$ STANRZECZY 2[9]/2015}


wiło do tej pory niepodważalną normę działania i postępowania, stawało się tekstem interpretacji, a nawet - naukowej krytyki. W swych badaniach przedstawiciele teologii liberalnej nie czuli się skrępowani wcześniej przyjętymi zasadami, uważając przyjęcie ich a priori za niezgodne z zasadami uprawiania nauki.

Z postulowanej przez Straussa naukowej krytyki Biblii w zakresie egzegezy wynikać miała wyłącznie „konkretyzacja” chrześcijaństwa, wydobycie zeń głównej idei, „zasady Chrystusa”. Jak pisze Węcławski, „[...] zasady obecnej w niej [Biblii] w postaci swoistego sygnału, czytelnego dla ducha rozumiejącego całość dziejów, jakkolwiek dla naiwnego i niekrytycznego czytelnika ukryta za naiwnie przyjmowanym przekazem bezpośrednim" (2005, 2007: 163).

Strauss swoje postulaty przedstawia jako program teoretyczny. Jednakże proponowane przezeń założenia w zestawieniu z właściwym niemieckiej teologii już od czasów Hrabana Maura (VIII/IX w., traktat Heliand, por. Ryś 1994) chętnym łączeniem tego, co polityczne i państwowe, z tym, co religijne i boskie, germanizacją teologii i swego rodzaju „optymizmem kulturowym", niosły ze sobą przynajmniej dwa brzemienne w skutki zjawiska. Po pierwsze, wyabstrahowana „idea chrześcijaństwa”, to, co pozostało z jego „konkretyzacji” (po odrzuceniu elementów niehistorycznych, nieudowadnialnych etc., etc.), wydawał się łatwo przekładać na realia współczesne Straussowi i jego następcom. Rzeczywistość, jaką znali i kształtowali (będąc, jak pamiętamy, urzędnikami państwowymi), zdawała się po prostu aktualną egzemplifikacją „zasady Chrystusa”, przystającą do mieszczańskiej moralności i takiegoż stylu życia. Po drugie, skupieni na historyczno-krytycznych badaniach uniwersyteccy teologowie praktycznie porzucili nie tylko pracę duszpasterską (opartą wedle teologów liberalnych na naiwnym, nienaukowym przekazie i egzegezie nieznajdującej uzasadnienia w źródłach), ale także, poprzez świadome podważenie źródeł wiary (znowu, jako nienaukowych i niemających uzasadnienia) - po części wyłączyli się ze wspólnoty wiary, stając się z jej członków - recenzentami.

Friedrich D.E. Schleiermacher, rozważając relację pomiędzy religia, metafizyką a moralnością, odrzuca zarówno religijną ortodoksję, jak i rozważania o charakterze moralnym lub metafizycznym. W eseju $O$ istocie religii stwierdza, że „nie wolno jej mieć żadnego kodeksu praw” (1995: 71) i że „nie pragnie ona określać i wyjaśniać natury wszechświata, jak robi to metafizyka, nie pragnie też dzięki sile wolności i boskiej samowoli człowieka dalej kształtować, [...] jak czyni to moralność” (tamże: 73). Jednocześnie pisze, że „każde pismo święte jest jedynie mauzoleum religii, pomnikiem 
świadczącym, że mieszkał w niej jakiś wielki duch, którego już nie ma [...]. Nie ten ma religię, kto wierzy w jakieś pismo święte, lecz ten, który nie potrzebuje żadnego, a sam mógłby jakieś stworzyć" (tamże: 111). W ustach duchownego i teologa ewangelickiego to pogląd dziś co najmniej zaskakujący.

Teologia, która miała stanowić próbę konkretyzacji, a przecież także i obrony chrześcijaństwa, w godzinie próby, jaką była I wojna światowa, okazała się bankructwem tak intelektualnym, jak religijnym. Teologia naukowców z uniwersyteckich gabinetów nie znajdowała odpowiedzi ani nie potrafiła udzielić wsparcia w czasie kryzysu i ludzkiej bezradności wobec cierpienia i zła. Przykładem tego, jak daleko mogły zawieść teologiczne rozważania i wynikające z protestantyzmu kulturowego wycofanie się z frontu duszpasterstwa w zacisze akademickiej katedry, było znalezienie się Adolfa von Harnacka, jednego z liderów nurtu, wśród pierwszych sygnatariuszy manifestu wyrażającego poparcie dla agresywnej polityki wojennej cesarza Wilhelma II.

Takie ryzyko tkwiło w metodzie przyjętej przez przedstawicieli i twórców teologii liberalnej. Próba apologii religii i wiary poprzez stosowanie metod wypływających z neopozytywizmu skutkowała zmiana pola zainteresowania teologii. Zamiast wyjaśniać i interpretować nauczanie Chrystusa czy prowadzić pogłębioną refleksję etyczną lub budować relację z Bogiem, za cel postawiono jedynie dokonywanie krytycznej analizy historycznej Pisma Świętego i prowadzenie intelektualnych dysput interpretacyjnych. Sfera aksjonormatywna, a więc także kaznodziejstwo i duszpasterstwo, musiały znaleźć się poza zainteresowaniem teologii, zwłaszcza akademickiej. W pamięci należy mieć też wywodzone z nauk Lutra, a upowszechnione w XVIII i XIX wieku, przekonanie o prywatności religii i fakt, że jej jedynym ,widzialnym” efektem miała być dobra, rzetelna praca i ewentualnie działalność społeczna (widoczna zwłaszcza w nurcie pietystycznym). W tej sytuacji teologowie nie tyle podporządkowali swoje działania władzy politycznej, ile zupełnie się ze sfery politycznej usunęli, by w zaciszu katedr i bibliotek snuć rozważania wnoszące bardzo wiele w historyczne badania nad religia, ale z nauczaniem Chrystusa związane w dużo mniejszym stopniu. Teologia była dyscyplina akademicka, więc musiała przyjmować wszystkie kryteria dyscypliny uniwersyteckiej. Nawet jeśli oznaczało to przesunięcie na dalszy plan tego, co jest osią nauki o Bogu i poznania Jego Słowa. Teologia liberalna miała być odpowiedzią na wyzwanie rzucone przez neopozytywistyczną akademię, pokazywać, że wiara jest możliwa do pogodzenia ze światopoglądem środowisk wykształconych. Kolejna godzina próby, jaką

\section{/ 148 STANRZECZY 2[9]/2015}


było dojście do władzy nazistów, pokazała jednak, że w czasie kryzysu nie wystarczy badać Pisma Świętego, by podążać za Chrystusem.

\section{/// Bonhoeffer}

Warunki, w których wychowywał się Bonhoeffer, sprzyjały podążaniu nurtem teologii akademickiej, neopozytywistycznej - wiary podporządkowanej rozumowi. W biografii pióra Eberharda Bethge, przyjaciela i wychowanka Bonhoeffera, czytamy:

Rodzina mieszczańskich intelektualistów, gdzie jedynymi argumentami w dyskusjach były konkrety, nie uznawała „nienaukowych" rozważań religijnych. Do kościoła oczywiście nie chodzono, religia była co najwyżej prywatną sprawą każdego z członków rodziny (cyt. za Milerski 1994: 118).

Jednakże, by oddać sprawiedliwość domowi rodzinnemu Bonhoeffera, trzeba przypomnieć przede wszystkim wartości, wokół których zorganizowane było życie rodziców i ośmiorga rodzeństwa. Zarówno ojciec, wzięty berliński psychiatra, jak i matka, córka i wnuczka pastora, choć z różnych pobudek (on - humanistycznych, ona - religijnych), wpajali dzieciom zasadę wolności i wynikającej z niej odpowiedzialności, życia dla innych i wrażliwości na ludzką krzywdę (por. Bethge 2003: 9-18, Ackermann 2007: 21-40, Kopiec 2008: 12-15). Anna Morawska pisze wprost, że dom ten był jednym z ośrodków berlińskiej elity intelektualnej, a co za tym idzie - myśli demokratycznej, republikańskiej, liberalnej, poczucia społecznej odpowiedzialności. Czyli wartości, które nakazały przeciwstawienie się Hitlerowi i ideologii niszczącej tak człowieka, jak Niemcy. Cechą charakterystyczna elit arystokratyczno-mieszczańskich było też - ważne dla moich dalszych rozważań nad Bonhoefferem - przesiąknięcie myślenia „formalistycznym, nieprzezwyciężalnym kultem litery prawa i kultem porządku (Ordnung)" (1970: 11-12)3.

Formalne założenia teologii liberalnej, związane z precyzja prowadzenia wywodu, starannym argumentowaniem, sceptycyzmem właści-

\footnotetext{
${ }^{3}$ Więcej na ten temat pisałam w artykule Teologia politycz̨na i etyka, opublikowanym w półroczniku „Nauka i Szkolnictwo Wyższe” (2013). Wskazuję w nim na sakralny stosunek zarówno jego otoczenia, jak i samego Bonhoeffera do obowiązujących przepisów prawa - nawet gdy przepisy te narzucone są przez zbrodniczy reżim. Źródła takiego podejścia upatruję w koncepcji niemieckiej drogi odrębnej (deutsche Sonderweg).
} 
wym ówczesnemu intelektualiście, wyznaczały sposób prowadzenia dyskusji i sporów - zarówno w domu rodzinnym Bonhoeffera, jak i na wybranym przezeń fakultecie teologicznym na Uniwersytecie Berlińskim. Bliski obydwu środowiskom był także bismarckowski z ducha niemiecki patriotyzm.

[Bonhoeffer] należał do swojej klasy społecznej, kochał ją, nigdy się jej nie zaparł. Ale od pierwszych lat dojrzałej egzystencji był z nią tak czy inaczej skłócony, nawet poniekąd skompromitowany wobec niej. Już sama emocjonalna intensywność i wyłączność jego zaangażowań religijnych była dość obca w tym środowisku [...]. Bonhoeffer szukał więc od początku jakiegoś innego, nowego »miejsca« dla siebie, jakby czuł, że tamto, domowe, nie wystarcza już, jest wiotkie, podcięte. Również wobec wszystkich zastanych teologii [...] był outsiderem i rewizjonista, i były one - jak już twierdził wprost - ,wiotkie, mgliste, pozbawione twardego gruntu pod nogami” (Morawska 1970: 12-13).

Już decyzja o podjęciu studiów teologicznych była swego rodzaju zakwestionowaniem ładu obowiązującego w otoczeniu Dietricha. Wszystkie późniejsze decyzje to zakwestionowanie pogłębiały, a spór czyniły ostrzejszym. W przypadku polemiki z teologia liberalną Bonhoeffer staje naprzeciw całej niemieckiej tradycji teologii ewangelickiej. Odrzucając jej współczesną mu interpretację i sposób uprawiania, pozostaje wierny jej duchowi i najgłębszemu przesłaniu teologii Lutra - a więc postawieniu w centrum wiary zasad solus Christus, sola Fide, sola Gratia i sola Scriptura.

\section{/// Bonhoeffera krytyka teologii liberalnej}

Kilka akapitów temu przedstawiłam główne założenia teologii liberalnej. Choć jej pierwotnym celem była obrona wiary i religii przed uznawaniem ich za sprzeczne z zasadami nauki i rozumu, prace części przedstawicieli tego nurtu sprawiaja, że w bardzo dużym uproszczeniu można ją określić jako sprowadzenie teologii do historyczno-krytycznych badań nad Biblią. Znacząco mniej ważne stało się formułowanie i rozważanie płynących z niej zasad moralnych, a w skrajnych przypadkach - nawet sama wiara w Boga. Dodatkowo wszystkie inne nurty teologii przedstawiano jako nieposiadające uprawomocnienia ze względu na brak zachowania zasad naukowości. 
Bonhoeffera krytyka teologii liberalnej odbywa się na dwóch poziomach. Polemizuje z nią zarówno na gruncie teoretycznym, jak i poprzez podjęte działania, a zwłaszcza - porzucenie błyskotliwej kariery akademickiej na rzecz pracy duszpasterskiej. Nie odrzuca natomiast rzetelności naukowej, właściwej teologom niemieckojęzycznym, i uczciwości intelektualnej - zmienia jednakże ich znaczenie. To, co dla teologów liberalnych było jedynie „możliwością niezależną” (Strauss), czyli przyjęcie Wcielenia i Objawienia za bezsporne fakty, dla Bonhoeffera jest fundamentem, na którym chrześcijanin ma budować wiarę i życie. „Nie jest jednak jakąś forma apriorycznego założenia; to sprowadzałoby Go [Chrystusa] do poziomu elementu, nieodzownego wprawdzie i niewymagającego udowodnienia, ale jednak składnika definiowania; Chrystus jest absolutnie pewną zasada naszej rzeczywistości. Bonhoefferowska teologia nie poszukuje dowodów na Jego istnienie [...]" (Kopiec 2008: 13). Tę pewność Bonhoeffer, tak jak każdy, kto dostępuje łaski wiary, po prostu ma.

Bonhoeffer dochodził stopniowo do tak opisanej kluczowej zasady Kościoła Chrystusa. Na początku lat 30. zaczęły krążyć zadziwiające dla akademików pogłoski, że „docent Bonhoeffer zrobił się pobożny”. Postanowił, że zawód teologa nie może być tylko pasjonująca przygodą intelektualną, ale przede wszystkim musi być pracą duszpasterską i służbą człowiekowi. Jego krytyka teologii liberalnej nie ma więc jedynie charakteru akademickiej polemiki czy udziału w teoretycznych debatach. Widać ją w podjętych decyzjach (porzucenie teologii teoretycznej na rzecz praktycznej) i powstałych równolegle z podjętymi decyzjami pismach - ukończonych książkach (Naśladowanie, Życie wspólne) i tekstach więziennych, składających się przede wszystkim na Etykę oraz Opór i poddanie.

\section{/// Przeciw konkretyzacji i redukcjonizmowi}

Wspomniana wcześniej „konkretyzacja chrześcijaństwa” - próba jego obrony poprzez zastosowanie wyłącznie akademickich standardów badań teologicznych w sytuacji pasywnej i wiernopoddańczej postawy Kościołów wobec nazistowskiego reżimu - zdaniem Bonhoeffera była bytem tyle abstrakcyjnym $\mathrm{i}$ istniejącym jedynie na papierze, ile szkodliwym, w swej istocie antychrześcijańskim i obcym tym, którzy wiarę rozumieją jako naśladowanie Chrystusa, nie zaś zadania intelektualne. Miał graniczące z pewnościa przeświadczenie, że obrana przez niego droga, idąca w poprzek ścieżek teologii akademickiej, jest tą właściwą. W liście do swojego brata KarlaFriedricha z dnia 14 stycznia 1935 roku pisał: 
Być może, pod pewnymi względami muszę wyglądać na fanatyka i wariata. Ale gdybym chciał być rozsądniejszy, musiałbym bowiem po prostu powiesić na kołku całą moją teologię. [...] Chyba wszedłem na właściwy trop, pierwszy raz w życiu. Wierzę i wiem, że mogę osiagnąć jaką́s jasność wewnętrzną i być naprawdę uczciwy, tylko gdy wezmę na serio Kazanie na Górze. [...] Są bowiem czasem rzeczy, dla których warto być całkiem bezkompromisowym. Wydaje mi się, że czymś takim jest pokój i sprawiedliwość społeczna czy właśnie Chrystus.

Efektem tych przemyśleń są bardzo konkretne decyzje o charakterze politycznym. Luterańskie chrześcijaństwo akademickich teologów liberalnych niezależnie od sytuacji politycznej pozostających wiernym swoim koncepcjom ${ }^{4}$ było w jego oczach bytem doktrynalnie i etycznie oderwanym od rzeczywistości, wiotkim i znajdującym się na marginesie zarówno życia społecznego, jak i osobistego. Za przyczyny fatalnej bezsilności Kościołów Ewangelickich Rzeszy wobec rasizmu, szowinizmu i nacjonalizmu, objawiającej się na przykład przyjęciem haniebnego „paragrafu aryjskiego", Bonhoeffer uważał z jednej strony społeczny i intelektualny konserwatyzm instytucji kościelnych, a z drugiej - istotny czynnik teologiczny, wynikający po pierwsze z błędnych w jego opinii założeń protestantyzmu kulturowego, po drugie zaś, mającej z nim polemizować, ale również oddalającej naśladowanie Chrystusa od jądra rozważań, akademickiej teologii liberalnej. Nie bez znaczenia jest również współczesna im Ordnungstheologie, „teologia porządku”, w której osiową wartością w życiu chrześcijanina jest dbałość o porządek publiczny, mający być emanacją boskiej woli.

Bonhoeffer stawia na teologię zaangażowaną społecznie i politycznie. Uważa, że takie zaangażowanie jest jego obowiązkiem jako chrześcijanina podążającego za Chrystusem. W 1937 roku publikuje będące owocem tych przemyśleń Naśladowanie (Nachfolge), którego przesłaniem jest radykalny chrystocentryzm. Pojęcie to ma oznaczać przekonanie, że pierwiastek Chrystusa jest obecny w każdym człowieku, bo za każdego poniósł On męczeńską śmierć na krzyżu. Wszak „kto gardzi człowiekiem, gardzi

\footnotetext{
${ }^{4}$ Nie dotyczy to wszystkich teologów liberalnych; przykładowo Rudolf Bultmann zarówno stworzył program „demitologizacji chrześcijaństwa”, jak i za kluczowa przyjmował żywą wiarę, polemizując z wcześniejszymi koncepcjami teologii liberalnej. W dziele Jesus wskazuje: „Bóg jest siła określającą moją konkretną egzystencję, a więc można o wszechmocy mówić tylko wtedy, gdy jej doświadczam w momencie, gdy na to pozwala mi Bóg, objawiając swoją moc" (Bultmann 1965: 121).
} 
tym, co Bóg ukochał, co więcej, gardzi postacią samego wcielonego Boga" (Bonhoeffer 1970: 162). Dlatego też chrześcijańskim obowiązkiem każdego wierzącego jest stosowanie się do Chrystusowego nauczania, zwłaszcza tego, zawartego w Kazaniu na Górze z Ewangelii św. Mateusza. Jednocześnie Bonhoeffer żywi przekonanie, że Boga należy doświadczać w świecie tam, gdzie są biedni, prześladowani i cierpiący, a nie w zaciszu uniwersyteckich gabinetów. Wierzy, że konieczne jest ciagłe poznawanie Jego Słowa, interpretowanie go i indywidualna relacja z Bogiem oraz wynikające z niej działanie:

Jego słowo, obojętnie, czy wypowiedziane podczas Jego ziemskiego życia, czy dziś [...], jest jednym i tym samym słowem. Tu i tam stanowi ono łaskawe wezwanie do Jego królestwa i pod Jego regiment [...]. Moim zadaniem jest wyłącznie słuchanie słowa i wypełnianie woli Chrystusa, objawionej w świadectwach. Pismo [...] głosi nam w każdym miejscu jednego Chrystusa. Tylko Jego mam słuchać. Ona zaś wszędzie jest tym samym, jednym Chrystusem. Tak więc na pytanie, gdzie my, ludzie współcześni, słyszymy wezwanie Jezusa do pójścia za Nim, nie ma innej odpowiedzi niż ta: słuchaj głoszonego słowa, przyjmuj Jego sakrament, usłysz w nich Jego samego, a usłyszysz Jego wezwanie! (Bonhoeffer 1997: 161162).

Tak rozumiana teologia stawiała Bonhoeffera z boku tak Kościoła, jak środowiska teologów akademickich. Z powodu czasu, w którym napisał Naśladowanie (1937 rok), powyższe słowa, daleko wykraczające poza ówczesną teologiczną normę interpretacyjną, dodatkowo stają się polityczne. Naśladowanie Chrystusa ma być bowiem niezmienne i niezależne od czasów i aktualnej polityki, a podmiotem działania, sposobem pójścia za Chrystusem - pomoc temu, kto jej najbardziej potrzebuje. Pytanie o to, kto po 1933 roku był „najsłabszym bratem” w nazistowskich Niemczech, wydaje się zbędne.

Bonhoeffer zdaje sobie sprawę z faktu, że jego teologia jest prowokacyjnie polemiczna wobec „poprawnej” politycznie współczesnej mu akademickiej teologii, w dużej mierze zdominowanej przez nurt liberalny, zarówno w zakresie sposobu jej uprawiania, jak i wniosków, do których go prowadzi. Wprost stwierdza, że każde powołanie człowieka przez Chrystusa jest w istocie jednym i tym samym faktem. Kwestie historyczności czy kontekstu kulturowego pozostają bez znaczenia. „Pismo głosi nam w każ- 
dym miejscu jednego Chrystusa", który zaprasza każdego do wybrania drogi, pójścia Jego śladem. W dodatku odrzuca „dogmat” współczesnych mu teologów, czyli sprowadzenie wiary i religii do kwestii czysto prywatnej, a także dostosowanie nauczania do warunków stworzonych przez władzę polityczna. Radykalne naśladowanie Chrystusa wyklucza takie kontrybucje na rzecz władzy.

Decyzja o odrzuceniu wszelkich ustępstw dla Bonhoeffera nie jest jednak Lutrową walką, do wytrwania w której musi się przymuszać. Lektura Naśladowania każe w objęciu go za sposób życia upatrywać raczej wyzwolenia, odkrycia drogi, która, choć trudna i bolesna, na pewno jest tą właściwa. Ksiądz prof. Bogusław Milerski stwierdza, że:

Spotkanie z Bogiem w samym życiu, w jego radościach jak i cierpieniu, było dla Bonhoeffera prawdziwym uwolnieniem. Doświadczenie Boga w świecie, poza tradycyjną kościelnością prowadziło do powstania teologii listów więziennych. Była to teologia zrozumiała dla nieteologów, odwołująca się do ich podstawowego doświadczenia: żyjemy i działamy w świecie bez Boga, ale w odpowiedzialności przed Bogiem. Tej odpowiedzialności przed Bogiem, poza wszelkimi ontologicznymi dociekaniami teologicznymi brakowało w czasach nazizmu ówczesnemu Kościołowi (1994: 120).

Dietrich Bonhoeffer, choć aż do śmierci z rąk nazistów przekonany o swej „niemieckości” i niemieckim patriotyzmie, specyficznie niemieckie myślenie o teologii ewangelickiej odrzuca z całą mocą. Wskazuje jego słabości teologiczne, a także - nieprzystawalność do aktualnej sytuacji społecznej i politycznej. Stwierdza, że pojmowanie teologii jako pozytywistycznie ujmowanej dziedziny badań naukowych bardziej niż osobistej refleksji nad tym, co Bóg przekazuje człowiekowi w Piśmie Świętym i jakie obowiązki na niego nakłada, choć tak bardzo pasujące i do niemieckiej nauki, i do niemieckiej tradycji teologicznej - jest de facto sprzeczne z idea chrześcijaństwa, zwłaszcza w warstwie jego obecności w świecie i relacji z bliźnim. Zwraca także uwage na to, że próba rozumowego poznania dobra i zła, bez dokonania prostego wyboru naśladowania Chrystusa, nieuchronnie prowadzi do porażki:

Wstrząający jest zawód, jakiego doznaja rozumni, którzy nie są w stanie zobaczyć otchłani zła ani otchłani świętości, i w najlepszej intencji wierza, że przy odrobinie rozsądku będą mogli utrzy- 
mać rozpadające się wiązania. Niezdolni do rozeznania chcą oddać sprawiedliwość obydwu stronom i wskutek tego - niczego nie osiągnąwszy - giną starci między dwiema napierającymi na siebie mocami. Gorzko rozczarowani nierozumnością świata, przekonani o bezowocności wysiłków, ustępują zrezygnowani albo też poddają się mocy silniejszego (Bonhoeffer 1970: 156).

Nietrudno się domyślić, jakich „rozumnych” Bonhoeffer miał tu na myśli. Sam, podjąwszy osobistą decyzję o naśladowaniu Chrystusa i bezwarunkowym poddaniu się Jego woli, zastanawia się, kim dla współczesnego człowieka jest Chrystus. Stwierdza, że „czasy, w których można było to powiedzieć człowiekowi za pomocą słów, czy to teologicznych, czy to pobożnych, już minęły. [...] Zmierzamy w kierunku całkowicie bezreligijnych czasów; ludzie nie mogą być już więcej religijni” (Bonhoeffer 1944, cyt. za Milerski 1994: 46).

Cytowany fragment listu nie dotyczy jednak (jak się często Bonhoeffera błędnie interpretuje) bezreligijnego chrześcijaństwa rozumianego jako coś na kształt chrześcijańskiego systemu norm i wartości bez konieczności wiary w Boga. Tym byłaby etyka wypływająca $z$ historyczno-krytycznych badań teologii liberalnej, tak mogłaby zostać przełożona na nauczanie „konkretyzacja chrześcijaństwa” czy nawet zbarbaryzowana wersja Bultmannowskiego programu jego „demitologizacji”. Bonhoeffer stawia podstawowe pytanie egzystencjalne: „Kim jest dla nas, dla mnie, Chrystus w czasach, które nie moga już być religijne?”.

Powołanie chrześcijanina jest zawsze takie samo - jest nim podążanie za Chrystusem. Jednak sposób tego podążania ma być dostosowany do aktualnej rzeczywistości. To w niej „człowiek ponosi odpowiedzialność za konkretnego bliźniego zgodnie z konkretnymi możliwościami” (Bonhoeffer 1970: 190). Z przekonania, że dziś, tu i teraz, we współczesnych mu czasach nazistowskiego terroru, Chrystus jest w każdym, zwłaszcza w najsłabszym z braci, i że jest Tym, Którego naśladowanie każe stanąć w ich obronie, wypływa Bonhoefferowska etyka. Kluczową kategoria jest odpowiedzialność za bliźniego; działania wypływające z tej odpowiedzialności człowiek składa w ręce Boga, zdaje się na Jego sąd i łaskę. Także wtedy, kiedy mówi, że rolą teologa i duszpasterza nie jest opatrywanie ran i pocieszanie wdów i sierot zabitych pod kołami niesprawiedliwości przez

\footnotetext{
${ }^{5}$ Więcej na temat etyki abstrakcyjnej i problemów z jej odniesieniem do rzeczywistego świata i trudności, jakie napotyka w nim człowiek, Bonhoeffer pisze w Etyce, w rozdziałach zatytułowanych Historia i dobro (s. 219-245) i we fragmencie rozdziału Etyka jako formacja (s. 97-102).
} 
szaleńca, ale - wyrwanie kierownicy z jego rąk (Bonhoeffer 2001). Jednym z działań, o których pisze Bonhoeffer, jest także uprawomocnione odpowiedzialnością za bliźniego i gotowością poniesienia odpowiedzialności za własne czyny zabicie tyrana.

Rozczarowanie kościołami instytucjonalnymi prowadzi Bonhoeffera do wniosku, że jedynym zadaniem Kościoła ma być służebność i „idea zastępczości” - miałby on przejąc ludzką winę, bronić słabszych i służyć człowiekowi, w którym tkwi przecież pierwiastek Chrystusa. Wiara chrześcijanina ma się więc przejawiać w konkretnym działaniu, w bezkompromisowym zaangażowaniu po stronie słabszych braci. Takie rozumienie teologii - jakże odmienne od założeń teologii liberalnej! - uczyniło z Bonhoeffera zarówno zdecydowanego pacyfistę, jak i zaangażowanego członka ruchu oporu. Związane z tym konsekwencje są w jego optyce nie tylko słuszne z prawno-etycznego punktu widzenia (wystąpienie przeciw prawu domaga się przewidzianej w nim kary, a jednorazowe złamanie zasady nie oznacza zawieszenia systemu prawnego, nawet jeśli jest z gruntu zły i gdy moralnym obowiązkiem chrześcijanina jest prawo złamać). Maja też charakter współżycia i cierpienia razem z Chrystusem; Bonhoeffer stwierdza bowiem, że Bóg nie tyle dopuszcza cierpienie, ile cierpi razem z człowiekiem (Bonhoeffer 1970: 160). Dlatego też przyszłe chrześcijaństwo ma się składać tylko z dwóch elementów - modlitwy i działania na rzecz bliźnich. Lektura i interpretacja Słowa Bożego jest dla nich obu niezbędna, ale jego celem jest lepsze poznanie słowa Chrystusa, by pełniej i bardziej świadomie móc Go naśladować w pomocy bliźniemu.

\section{/// Podsumowanie}

Krytyka teologii liberalnej prowadzona przez Bonhoeffera ma charakter zarówno teologiczny, teoretyczny, jak i społeczny, praktyczny. Postulowany przezeń radykalny chrystocentryzm wyklucza poprzestanie na badaniach nad moralnym przesłaniem Chrystusa, gdy konieczne jest naśladowanie Go. Prowadzenie badań historyczno-krytycznych nad Pismem Świętym nie jest w jego optyce dążeniem do gruntownego poznania i zrozumienia nauczania Chrystusa, ale wygodną furtką do ominięcia Jego kłopotliwych nakazów - nawet pomimo apologetycznego programu teologii liberalnej. Furtka ta prowadzi do działań antychrześcijańskich, marginalizuje wezwanie do naśladowania Chrystusa. Naśladowania, które jest aktywnością na rzecz bliźnich, przejęciem odpowiedzialności, a nie rozważaniem teoretycznym. Kościół będący Kościołem Jezusa Chrystusa, a nie

\section{/ 156 STANRZECZY 2[9]/2015}


jedynie formalną organizacją, nie może zalecać zamknięcia się w prywatnej pobożności ani nawet prowadzenia - skądinąd słusznych - rozważań na gruncie akademickim, gdy historia wymaga od niego zajęcia wyraźnego stanowiska - stanięcia po stronie wykluczonych z człowieczeństwa.

Bonhoefferowska krytyka teologii liberalnej nie polega jedynie (właściwie: głównie nie polega) na prowadzeniu akademickiego dyskursu. To nie miałoby sensu i w istocie byłoby „oddaniem pola” i przyznaniem, że miejscem uprawiania teologii są wyłącznie uniwersyteckie mury. Bonhoeffer udowadnia, że kształt, a nawet podstawowe założenie teologii liberalnej, są błędne, że choć chce ona bronić religii i wiary przed bezrefleksyjnym protestantyzmem kulturowym i podejmuje próbę uprawomocnienia teologii na gruncie akademickim, to de facto im się - przynajmniej po części - podporządkowuje. Pokazuje, że krytykowany przez Bartha kulturowy, wycofany do sfery prywatnej ewangelicyzm nie ma nic wspólnego z naśladowaniem Chrystusa. Jednak swój dyskurs prowadzi przede wszystkim za pomoca czynów. Udowadnia, że Lutrowe przekonanie o konieczności prowadzenia aktywnej pracy duszpasterskiej, a nie jedynie akademickich rozważań, jest właściwa formą realizacji powołania teologa. Jego miejsce jest u boku najsłabszych braci, a zadaniem - stanięcie w ich obronie. Nawet, a może zwłaszcza, jeśli sprawia to, że wygodny uniwersytecki gabinet przyjdzie zamienić na więzienną celę.

Bibliografia:

/// Ackermann J. 2007. Dietrich Bonhoeffer. Wolnośc ma otwarte oczy, tłum. E. Pieciul-Karmińska, Wydawnictwo Polskiej Prowincji Dominikanów „W drodze”.

/// Bethge E. 1970. Dietrich Bonhoeffer. Theologe - Christ - Zeitgenosse. Eine Biographie, Chr. Kaiser Verlag.

/// Bethge E. 2003. Dietrich Bonhoeffer. Świadek Ewangelii w trudnych czasach, tłum. B. Milerski, Augustana.

/// Bonhoeffer D. 1970. Wybór pism, tłum. i red. A. Morawska, Biblioteka „WIĘZI”.

/// Bonhoeffer D. 1997. Naśladowanie, tłum. J. Kubaszczyk, Wydawnictwo Polskiej Prowincji Dominikanów „W drodze”. 
/// Bonhoeffer D. 2009. Ethics, red. I. Tödt, H.E. Tödt, E. Feil, C. Green, tłum. R. Krauss, Ch.C. West, D.W. Stott, Fortress Press.

/// Bonhoeffer D. 2001. Życie wspólne, tłum. K. Wójtowicz, Wydawnictwo Alleluja.

/// Bultmann R. 1965. Jesus, Siebenstern Taschenbuch Verlag.

/// Hintz M. 2003. Teologia liberalna [w:] Religia. Encyklopedia PWN, red. T. Gadacz, B. Milerski, t. 9, Wydawnictwo Naukowe PWN, s. 274.

/// Hegel G.W.F. 1958. Wykłady z filozofii driejón, tłum. J. Grabowski, i A. Landmann, Wydawnictwo Naukowe PWN, Warszawa.

/// Jędrzejczak H.A. 2013. Teologia polityczna i etyka, „Nauka i Szkolnictwo Wyższe", nr 1(41), s. 12-28.

/// Kant I. 1993. Religia w obrebie samego rozumu, tłum. A. Bobko, Znak.

/// Kopiec P. 2008. Kościót dla śmiata. Wiarygodność kościoła w teologicænej interpretacji Dietricha Bonhoeffera, Wydawnictwo KUL.

/// Lessing G.E. 1979. Theologiekritische Schriften III; Philosophische Schriften, red. H. Göpfert, Hauser.

/// Milerski B. 1994. Religia a Stowo. Krytyka religii w ujeciu Dietricha Bonhoeffera i Paula Tillicha, Wydawnictwo Ewangelickie Świętego Mateusza.

/// Morawska A. 1970. Chržeścijanin w Tržeciej Ržeszy, Biblioteka „Więzi”.

/// Napiórkowski A. 2006. Eklezjologia Dietricha Bonboeffera - czyli Kościót $w$ beareligijnym świecie, [w:] Wierzyć w Tego samego i tak samo. Ekumeniczna dogmatyka Dietricha Bonhoeffera. Praca zbiorowa, red. J. Lipniak, Świdnicka Kuria Biskupia, s. 53-68.

/// Reimarus H.S. 2005. Apologia albo Pismo w obronie rozumnych czcicieli Boga, [w:] Praeceptores. Teologia i teologowie jezylka niemieckiego, red. T. Węcławski, E. Piotrowski, Wydawnictwo Poznańskie.

/// Ryś G. 1994. Heliand - Chrystus saksońskich baronów, „Znak”, nr 9, s. $72-79$.

/// Schilling H. 2010. Konfesjonalizacja. Kościót i państwo w Europie doby przednowoczesnej, tłum. J. Kałążny, Wydawnictwo Poznańskie. 
/// Schleiermacher F.D.E. 1995. Mowy o religii do wylesztatconych spośród tych, którzy nia gardzq, tłum. J. Prokopiuk, Wydawnictwo Znak.

/// Strauss D.F. 2005. Życie Jezusa krytycznie opracowane, tłum. E. Pieciul, [w:] Praeceptores. Teologia i teologowie jezyka niemieckiego, red. T. Węcławski, E. Piotrowski, Wydawnictwo Poznańskie, s. 305-311.

/// Węcławski T. 2005a. Teologia niemieckojezyczna w stuleciach XIX i XX - rys bistoryczny, [w:] Praeceptores. Teologia i teologowie jezyke niemieckiego, red. T. Węcławski, E. Piotrowski, Wydawnictwo Poznańskie, s. 157-184.

/// Węcławski T. 2005b, 2007. Uwagi wstepne - koncept antologii, [w:] Praeceptores. Teologia i teologowie jezyka niemieckiego, red. T. Węcławski, E. Piotrowski, Wydawnictwo Poznańskie, s. 7-11.

\section{/// Abstrakt}

W niniejszym artykule przedstawiam główne założenia niemieckiej ewangelickiej teologii liberalnej na podstawie tekstów Friedricha D.E. Schleiermachera i Davida F. Straussa. Zestawiam je z myślą teologiczna (radykalnym chrystocentryzmem, etyka praktyczna) Dietricha Bonhoeffera, znajdująca odbicie w podejmowanych przez niego działaniach - zarówno politycznych, jak i duszpasterskich, teologicznych.

W pracy nad esejem posługiwałam się metodologią właściwą historii idei. W związku z tym w eseju pokazuję także kontekst ideowy i historyczny powstania omawianych tekstów i prądów intelektualnych. Ważnymi tropami sa tu oświecenie niemieckie, model niemieckiej ewangelickiej religijności i tradycja katolickiej i ewangelickiej teologii niemieckojęzycznej. W eseju pokazuję, w jaki sposób myśl Bonhoeffera jednocześnie doskonale się w nie wpisuje i całkowicie im zaprzecza.

Słowa kluczowe:

Bonhoeffer, teologia liberalna, Chrystus, Niemcy, teologia niemiecka

\section{/// Abstract}

In this article I show the main assumptions of the German Lutheran liberal theology, based on the thought and texts of its most important repre- 
sentatives: Friedrich D.E. Schleiermacher and David F. Strauss. I compare it with Dietrich Bonhoeffer's theological thought (radical Christocentrity, practical ethics), which was reflected in his decisions and activity - both political and theological, pastoral.

Since the history of ideas methodology was used during work on the essay, the text also points out the elements of the intellectual climate and historical background of these texts and intellectual currents, which may have influenced thoughts and works. Important ones are: German Enlightenment, German model of religiosity, and the tradition of Germanspeaking theology, both Catholic and Lutheran. In this essay, I show how Bonhoeffer's thought at the same time perfectly fits in there and completely contradicts them.

Key words:

Bonhoeffer, liberal theology, Jesus Christ, Germany, German theology 